\title{
PYROCHLORE FROIM THE SOKLI CARBONATITE COMPLEX, NORTHERN FINLAND
}

\author{
KRISTIAN LINDQVIST and PENTTI REHTIJÄRVI
}

\begin{abstract}
LINDQVIST, KRISTIAN and REHTIJÄRVI, PENTTI 1979: Pyrochlore from the Sokli carbonatite complex, Northern Finland. Bull. Geol. Soc. Finland 51, 81-93.

Pyrochlore from the Sokli carbonatite complex has been studied in four phoscorite and two regolith samples. The crystal forms of the euhedral pyrochlores are either an octahedron or a combination of an octahedron and a cube. Twinning according to the spinel law was found on two occasions. Zoning and inclusions are common. After the recrystallization of metamict pyrochlore, fersmite and lueshite phases also occur in addition to the pyrochlore phase. Cell dimensions for the recrystallized pyrochlore vary between $10.375 \AA$ and $10.426 \AA$. The $\mathrm{Ce} / \mathrm{La}$-ratio varies between 3.1 and 9.6 . The low $\mathrm{Nb}_{2} \mathrm{O}_{5} / \mathrm{Ta}_{2} \mathrm{O}_{5}-$ ratio $(4.9-177.9)$ indicates that the pyrochlore was crystallized in a relatively undifferentiated magma.

In weathering uranium is leached from pyrochlore and, as indicated by distribution studies, is rebound in supergene secondary minerals or amorphous material. A pyrochlore factor with heavy loading for uranium was found in a statistical study of an analyzed vertical sample series from weathered carbonatite.
\end{abstract}

Kristian Lindqvist ${ }^{1}$ and Pentti Rehtijärvi, ${ }^{1}$ Department of Geology, University of Helsinki, P.O. Box 115, SF-00171 Helsinki 17. Finland.

\section{Introduction}

The main geological features of the Sokli carbonatite complex have been given by Paarma (1970). Vartiainen and Woolley (1974, 1976) have discussed the age of the intrusion and its relation to the North Atlantic alkaline igneous province, and described the extensive aureole of fenites enveloping the plug. Paarma and Talvitie (1976) have discussed the tectonic and structural position of the intrusion and attributed the deposition of the Sokli plug to the opening of the Kantalahti deep fracture zone. Mäkelä and Vartiainen

1 Present address: Geological Survey of Finland, SF-02150 Espoo 15, Finland.
(1978) have given the S-isotope data for sulphides in the proposed magmatometasomatic stages of the multi-stage carbonatite, established the temperature order of the stages, and presented an estimate of the temperature range of formation, from $600^{\circ} \mathrm{C}$ to $300^{\circ} \mathrm{C}$. Pyrochlore from the complex is described in the present study.

The main rock types in the complex are phoscorites, silicosövites, sövites and rauhaugites. Calcite-rich carbonate rocks are dominant. Pyrochlore is present in all the main types of carbonatite and enriched in phoscorites (Paarma 1970). Phoscorites characterize the proposed stages I and III of the multistage carbonatite succession (Mäkelä and Var- 
tiainen 1978). The phoscorites of stage I are medium- to coarse-grained and massive in texture. Serpentinization of olivine is the only typical alteration phenomenon of these rocks. The heterogeneous phoscorites of stage III, which are considered post-intrusive metasomatic derivatives of the phoscorites of stage I, are distinguished by the presence of red phlogopite (tetraferriphlogopite), clinohumite and amphiboles.

\section{Material and methods}

Pyrochlore was investigated in six samples and a statistical study was made of the chemistry of a vertical sample series from weathered carbonatite, with special reference to the distribution of uranium. Pyrochlore was studied from the drill core samples 1003, 1004, 1008 and 1014 and from the regolith samples M 05 and M 06. The drill core samples are phoscorites with a main mineral composition as presented in Table 1 . The regolith samples M 05 and M 06 belong to the vertical, 3.2 $\mathrm{m}$ deep series of 13 analyzed samples, M 01M 13, from weathered carbonatite (see Fig. 6). All the samples are from the northern and northeastern parts of the complex.

A Philips wide-angle goniometer with Nifiltered $\mathrm{Cu}_{\mathrm{K} \alpha}$-radiation was used in the $\mathrm{X}$ ray diffraction studies. The cell dimensions were calculated using the XRAY-PARAM program of Ammon and Mauer (1967).
Heating in argon atmosphere was carried out in a Rigaku-Denki $8001 \mathrm{H}-1500^{\circ} \mathrm{C}$ DTA/TGapparatus at a rate of $10^{\circ} \mathrm{C} / \mathrm{min}$ up to $1000^{\circ} \mathrm{C}$. As recommended by Lima de Faria (1958, 1964) the pyrochlore concentrates, when heated in air, were kept for $1 \mathrm{~h}$ at $1000^{\circ} \mathrm{C}$. According to Adams and Sharp (1970) heating studies of multiple oxides should be done both in air and in an inert atmosphere, especially when the recrystallization of different phases is being studied. To find out the effects of time on the recrystallization, an aliquot of the pyrochlore concentrate 1003 was also kept for $5 \mathrm{~h}$ at $1000^{\circ} \mathrm{C}$. The electron probe microanalyses of the pyrochlore samples were carried out with a Cambridge Geoscan microprobe at Rautaruukki Oy, Raahe. The intensity data'were corrected using the EMPADR VII program of Rucklidge and Gasparrini (1969). The regolith samples were analyzed by Rautaruukki Oy at Raahe using mainly the X-ray fluorescence method. The correlations and $\mathrm{R}$-mode rotated factors were calculated with the HYLPS statistical and mathematical program package developed by the Computing Centre, University of Helsinki. The distribution of uranium and thorium, or of uranium alone, was mapped, using either and autoradiographic method with Kodak CA $80-15$ film or thermal neutron induced fission tracks with Bayer, Makrofol N $20 \mu \mathrm{m}$ detectors (cf. Rehtijärvi and Liehu 1977), respectively.

Table 1. Modal composition of phoscorites from Sokli (point counting).

\begin{tabular}{lcccr}
\hline & 1003 & 1004 & 1008 & 1014 \\
\hline Drill code & $\mathrm{R} 260$ & $\mathrm{R} 274$ & $\mathrm{R} 289$ & $\mathrm{R} 330$ \\
Depth (m) & $26.7-28.5$ & $48.0-53.0$ & $124.0-124.3$ & 76.0 \\
\hline Pyrochlore & 2.6 & 4.9 & 2.1 & 7.3 \\
Magnetite & 26.1 & 20.5 & 20.5 & 26.5 \\
Mica & 3.5 & 9.3 & 2.1 & 27.0 \\
Apatite & 18.3 & 19.5 & 19.6 & 21.0 \\
Carbonate & 3.5 & 4.3 & -3.6 & - \\
Olivine & 18.3 & - & - & - \\
Serpentine & 24.5 & 39.2 & - & 3.5 \\
Clinohumite & - & 2.3 & 3.5 & 1.9 \\
Others & 3.2 & & & \\
\hline
\end{tabular}



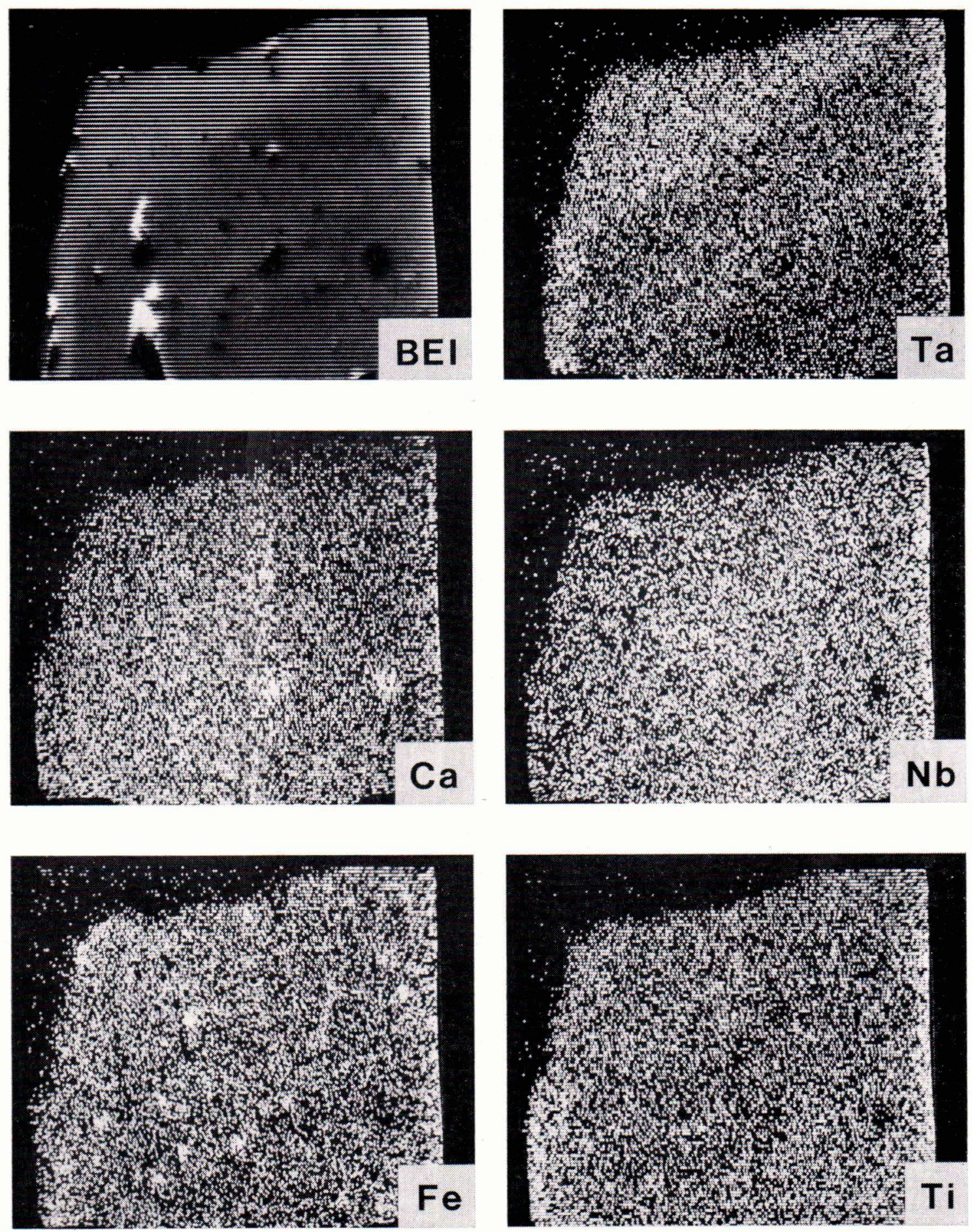

\section{$0.1 \mathrm{~m} \mathrm{~m}$}

Fig. 1. Back-scattered electron image (BEI) and the distribution patterns for $\mathrm{Ta}, \mathrm{Nb}, \mathrm{Ti}, \mathrm{Ca}$ and $\mathrm{Fe}$ in pyrochlore from phoscorite sample 1004. Photos by Dr. Jaakko Siivola, Geological Survey of Fin- 
Table 2. X-ray data for the heated (recrystallized) pyrochlore concentrates from Sokli.

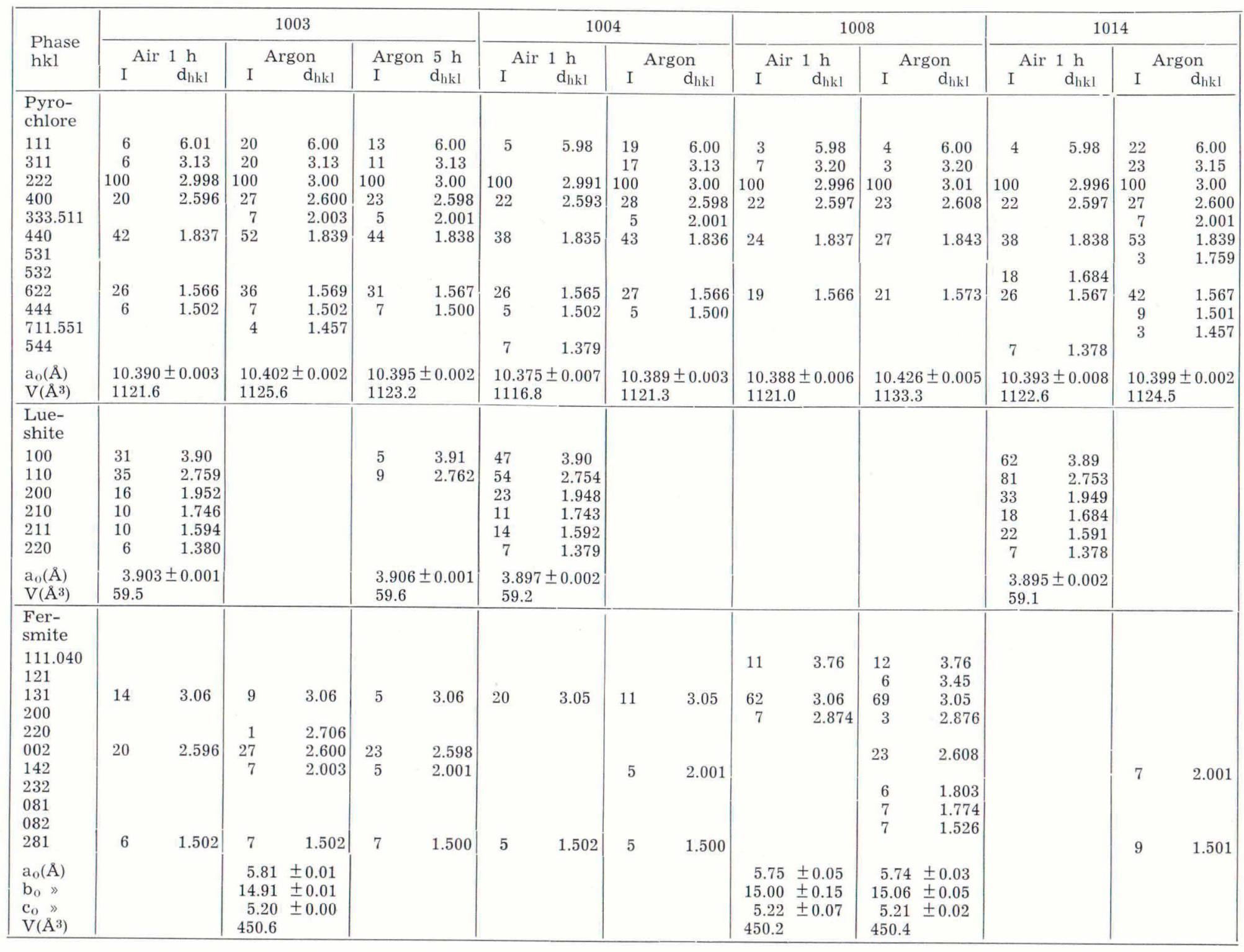




\section{Pyrochlore minerals}

Crystal habit, zonality and inclusions

The pyrochlore occurs as brown euhedral grains varying in size from $0.15 \mathrm{~mm}$ to 0.5 $\mathrm{mm}$, and occasionally as large as $5 \mathrm{~mm}$. The prevailing crystal forms are an octahedron or a combination of an octahedron and a cube. Pyrochlore twins were found in the samples 1003 and 1014. The twinning follows the spinel law and the twin plane is (111). Pyrochlore twins have been described earlier from the Lueshe carbonatite complex by Safiannikoff (1967). Frondel (1958) and van der Veen (1963) report twinning to be rare in minerals belonging to the pyrochlore group.

Zoning seems to be marked and common in the Sokli pyrochlore. In the pyrochlore of sample 1004 tantalum together with uranium and/or thorium shows zonal distribution (Figs. 1 and 2). However, in most cases there are no significant differences in the distribution of the main components. According to van der Veen (1963) such zonality is due to metamictization. Petruk and Owens (1975) reported only minor differences in the distribution of the main components of zonal pyrochlore from the Oka carbonatite complex, the greatest differences being found in the distribution of iron, uranium and thorium.

A grey or greenish grey mantle can be seen around the weathered Sokli pyrochlore grains. Semenov et al. (1968) identified the greyish green non-transparent substance in the altered marginal zone of brown pyrochlore from Ilimaussaq as igdloite (lueshite). According to van der Veen (1963) pyrochlore from the Mbeya carbonatite complex alters first to fersmite, later on to columbite.

Magnetite, apatite and carbonate inclusions are common in the Sokli pyrochlore grains. Also, a Hf-rich $\mathrm{ZrO}_{2}$-mineral (?) was found in pyrochlore from sample 1008. According to Heinrich (1966) magnetite inclusions are

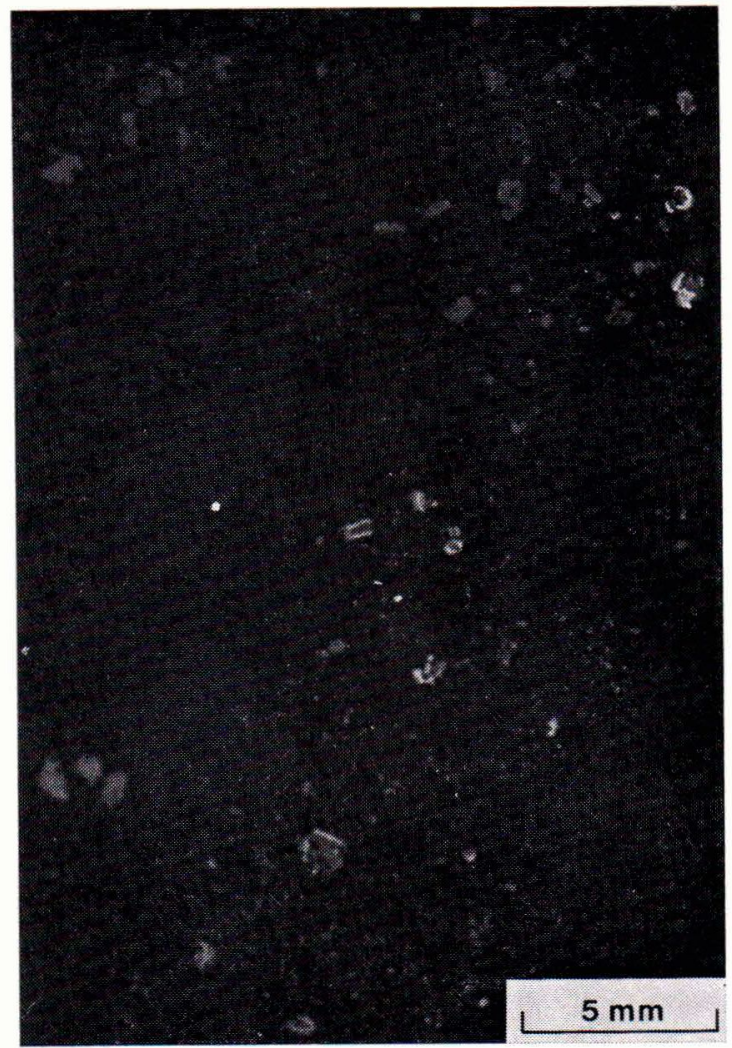

Fig. 2. Zonal distribution of uranium and thorium in pyrochlore from phoscorite sample 1004. Kodak CA $80-15$ film, radiation time 26 d. The phoscorite sample contained $108 \mathrm{ppm}$ of $\mathrm{U}$ and 1263 ppm of Th (INAA method).

common in pyrochlore. The larger pyrochlore crystals in the Mbeya carbonatite generally contain apatite, calcite, iron oxide and fluorite inclusions (Fawley and James 1955). von Eckermann (1974) reports wollastonite inclusions in pyrochlore from Alnö, Wimmenauer (1964) apatite inclusions in pyrochlore from Kaiserstuhl, and Deutzmann (1964) rutile inclusions in zoned varieties of dark pyrochlore from Kaiserstuhl.

\section{Thermal behaviour}

No thermal reactions could be recorded during the heating of pyrochlore concentrates 


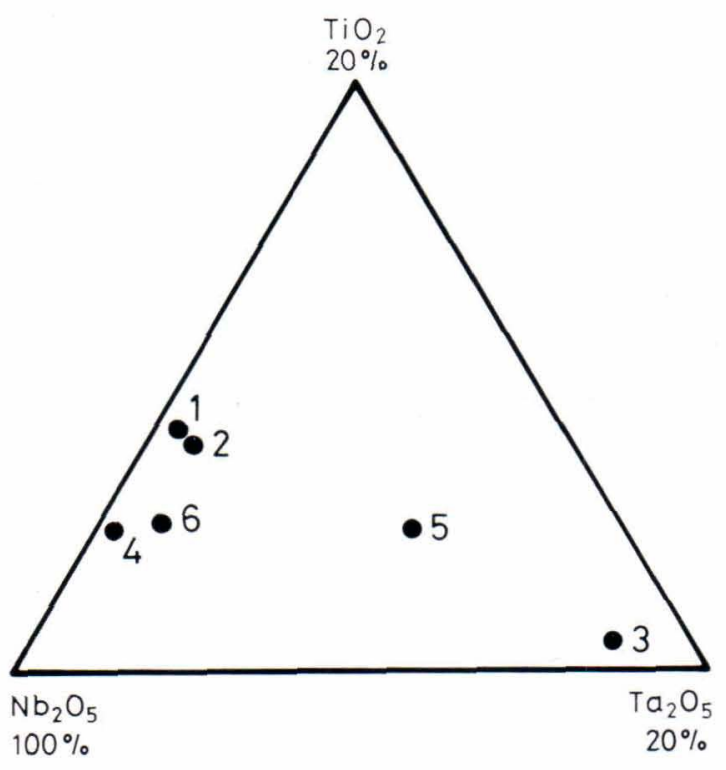

Fig. 3. $\mathrm{Nb}_{2} \mathrm{O}_{5-}$, $\mathrm{TiO}_{2-}$ and $\mathrm{Ta}_{2} \mathrm{O}_{5}$-weight proportions in pyrochlore from samples 1003 (1), 1004 (2), 1008 (3), 1014 (4), M 05 (5) and M 06 (6).

from the samples 1003, 1004 and 1008. In earlier studies on the thermal behaviour of pyrochlore, Kulp et al. (1952) and Krivokoneva and Sidorenko (1971) obtained similar negative results. According to Jäger et al. (1959), weak exothermal peaks may arise at $400^{\circ} \mathrm{C}$ and $600^{\circ} \mathrm{C}$. The peak temperature depends on the state of oxidation and the rate of recrystallization. Pyrochlore from sample 1014 exhibited an exothermal reaction at $540^{\circ} \mathrm{C}$, which may have been due to the recrystallization of pyrochlore (cf. Gorzhevskaya and Sidorenko 1962).

The mean loss of weight in the heating of the pyrochlore concentrates was $8.9 \%$. Similar results have earlier been attributed to the loss of water (Vlasov 1966). The loss of weight of the pyrochlore concentrate from sample 1003 did not continue under prolonged heating, $5 \mathrm{~h}$ at $1000^{\circ} \mathrm{C}$.

During the heating studies, both in argon and in air, the pyrochlore concentrates turned yellow or reddish yellow.

\section{$X$-ray diffraction studies}

The unheated pyrochlore proved to be metamict. The unit cell dimensions for the recrystallized pyrochlore varied between $10.375 \AA$ and $10.426 \AA$. The length of the a-axis for the pyrochlore phase recrystallized in air was found to be less than for the corresponding phase recrystallized in argon (Table 2). Three mineral phases were identified: pyrochlore, fersmite $\left(\mathrm{CaNb}_{2} \mathrm{O}_{6}\right)$ and lueshite $\left(\mathrm{NaNbO}_{3}\right)$. The generation of lueshite seems to be favoured by the air atmosphere. Gorzhevskaya and Sidorenko (1962) have obtained perowskite and fersmite when heating metamict pyrochlore, and lueshite when heating crystallized pyrochlore. Lima de Faria (1964) has, in addition to some unidentified reflections, obtained three phases when heating pyrochlore: a pyrochlore phase with $\mathrm{a}_{0}=10.4 \AA$, a cubic $\mathrm{NbO}_{2}$-phase, and a fersmite phase. The metaniobate $\left(\mathrm{Na}_{2} \mathrm{Nb}_{2} \mathrm{O}_{6}\right)$ crystallized by Sørum (1955), during heating of pyrochlore from Søve with calcium oxide, exhibits the same powder pattern as lueshite.

\section{Chemical composition}

The chemical composition of the pyrochlore minerals is presented in Table 3 , with reference samples from Alnö and Oka included for comparison. The atomic proportions between the A-atoms in pyrochlore (general formula $\left.\mathrm{A}_{2-\mathrm{m}} \mathrm{B}_{2} \mathrm{O}_{6}(\mathrm{O}, \mathrm{OH}, \mathrm{F})_{1-\mathrm{n}} \cdot \mathrm{pH}_{2} \mathrm{O}\right)$ from the phoscorite samples are presented in Table 4. The pyrochlore from sample 1008 proved to be uranpyrochlore (cf. Hogarth 1977).

In the pyrochlore from the samples studied, the Ce/La-ratio varies between 3.1 and 9.6. The proportions of the B-atoms ( $\mathrm{Nb}, \mathrm{Ta}, \mathrm{Ti})$ are presented in Fig. 3. The pyrochlore minerals contain a notable amount of tantalum; the $\mathrm{Nb}_{2} \mathrm{O}_{5} / \mathrm{Ta}_{2} \mathrm{O}_{5}$-ratio varies between 4.9 and 
Table 3. Chemical composition of the pyrochlore minerals from Sokli, with reference samples from Alnö, Sweden (von Eckermann 1974) and Oka, Canada (Petruk and Owens 1975) included for comparison $(\%$, n.d. $=$ not detected).

\begin{tabular}{|c|c|c|c|c|c|c|c|c|}
\hline & 1003 & 1004 & 1008 & 1014 & M 05 & M 06 & Alnö & Oka \\
\hline $\mathrm{Al}_{2} \mathrm{O}_{3}$ & 0.00 & 0.03 & 0.16 & 0.07 & 0.11 & 0.06 & 0.00 & n.d. \\
\hline $\mathrm{SiO}_{2}$ & 0.04 & 0.05 & 0.61 & 0.01 & 0.01 & 0.04 & 0.00 & 3.16 \\
\hline $\mathrm{CaO}$ & 17.75 & 16.63 & 9.29 & 18.18 & 11.64 & 13.62 & 17.01 & 5.06 \\
\hline $\mathrm{TiO}_{2}$ & 5.08 & 4.45 & 0.57 & 2.83 & 2.52 & 2.78 & 6.06 & 5.14 \\
\hline $\mathrm{MnO}$ & 0.04 & 0.07 & 0.08 & 0.09 & 0.04 & 0.03 & 0.30 & 0.23 \\
\hline $\mathrm{FeO}$ & 0.22 & 2.47 & 1.30 & 0.70 & 1.02 & 0.31 & 0.24 & 3.00 \\
\hline $\mathrm{Fe}_{2} \mathrm{O}_{3}$ & & & & & & & 2.40 & \\
\hline $\mathrm{Ce}_{2} \mathrm{O}_{3}$ & 1.99 & 1.38 & 1.01 & 0.89 & 0.93 & 0.43 & & 3.49 \\
\hline $\mathrm{Ce}(\mathrm{La}) \mathrm{O}_{2}$ & & & & & & & 0.16 & \\
\hline $\mathrm{La}_{2} \mathrm{O}_{3}$ & 0.56 & 0.22 & 0.11 & 0.12 & 0.16 & 0.14 & & 0.79 \\
\hline $\mathrm{ThO}_{2}$ & 5.26 & 3.67 & 2.08 & 5.17 & 3.51 & 3.98 & 1.32 & n.d. \\
\hline $\mathrm{U}_{3} \mathrm{O}_{8}$ & 0.21 & 0.30 & 27.52 & 0.34 & 11.64 & 7.44 & 0.03 & 20.73 \\
\hline $\mathrm{Nb}_{2} \mathrm{O}_{5}$ & 55.70 & 52.19 & 48.94 & 55.16 & 44.29 & 52.30 & 61.87 & 49.62 \\
\hline $\mathrm{Ta}_{2} \mathrm{O}_{5}$ & 0.34 & 0.80 & 10.01 & 0.31 & 4.71 & 0.98 & 0.10 & 3.88 \\
\hline $\mathrm{ZrO}_{2}$ & 0.29 & 2.20 & 3.35 & 1.77 & 4.03 & 3.36 & 2.55 & 0.27 \\
\hline $\mathrm{F}$ & 4.4 & 5.7 & 1.6 & 3.3 & 1.6 & 3.6 & 2.75 & \\
\hline $\mathrm{Na}_{2} \mathrm{O}$ & $3.91^{1}$ & $3.72^{1}$ & $1.16^{1}$ & $4.45^{1}$ & & & 3.33 & 0.00 \\
\hline $\mathrm{SrO}$ & & & & & & & & 1.18 \\
\hline MgO & n.d. & n.d. & n.d. & n.d. & n.d. & n.d. & 0.58 & n.d. \\
\hline $\mathrm{K}_{2} \mathrm{O}$ & & & & & & & 0.26 & \\
\hline $\mathrm{Nd}_{2} \mathrm{O}_{3}$ & & & & & & & & 0.58 \\
\hline $\mathrm{H}_{2} \mathrm{O}^{+}$ & & & & & & & 2.13 & \\
\hline $\mathrm{H}_{2} \mathrm{O}^{-}$ & & & & & & & 0.28 & \\
\hline
\end{tabular}

1 Instrumental neutron activation analysis (INAA)

177.9. The $\mathrm{Nb}_{2} \mathrm{O}_{5} / \mathrm{Ta}_{2} \mathrm{O}_{5}$-ratio in pyrochlore from various carbonatite locations varies between 7 and 6000 , mostly between 100 and 500 (van der Veen 1963). The highest values are found for pyrochlore crystallized from a differentiated magma in late-magmatic or post-magmatic stages. Pyrochlore from Kaiserstuhl, for example, shows a $\mathrm{Nb}_{2} \mathrm{O}_{5} / \mathrm{Ta}_{2} \mathrm{O}_{5-}$ ratio mainly about 600 , a value that is con-

Table 4. A-atom proportions in pyrochlore minerals $(\%)$.

\begin{tabular}{lrrrr}
\hline & 1003 & 1004 & 1008 & 1014 \\
\hline $\mathrm{Fe}$ & 0.6 & 7.2 & 5.4 & 1.9 \\
$\mathrm{Ca}$ & 65.6 & 62.2 & 49.4 & 64.1 \\
$\mathrm{Na}$ & 26.2 & 25.2 & 11.2 & 28.4 \\
$\mathrm{U}$ & 0.2 & 0.2 & 29.3 & 0.2 \\
$\mathrm{Ce}$ & 4.1 & 1.8 & 1.8 & 1.1 \\
$\mathrm{La}$ & 2.5 & 0.3 & 0.2 & 0.1 \\
$\mathrm{Th}$ & 0.7 & 2.9 & 2.4 & 3.9 \\
$\mathrm{Mn}$ & 0.1 & 0.2 & 0.3 & 0.3 \\
\hline
\end{tabular}

sidered typical of carbonatites (van Wambeke 1964).

Uranium is readily leached from pyrochlore during weathering processes and rebound in supergene minerals and substances. The weathered pyrochlore grains are lighter in colour than the unweathered grains and are surrounded by a grey or greenish grey mantle. The only notable radioactive mineral in the phoscorite is pyrochlore (see Fig. 2 and Fig. 4). In weathered (regolith) samples in addition to pyrochlore also secondary apatite and fine-grained limonite contain marked amounts of uranium (Fig. 5). Ferric hydroxides and amorphous substances are known to have a considerable capacity for sorbing uranyl ions (Lovering 1955, Rozhkova et al. 1958, Weijden et al. 1976). According to Altschuler et al. (1958) and Rozhkova et al. (1958), calcium phosphate may also concentrate uranium from surrounding waters. 


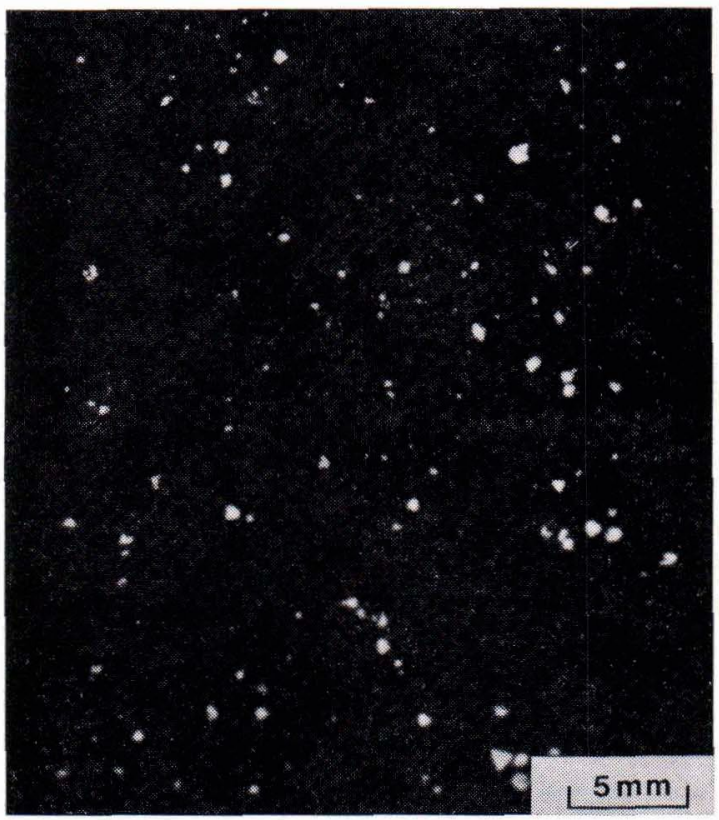

Fig. 4. Distribution of uranium and thorium in phoscorite sample 1008. Kodak CA 80-15 film, radiation time 26 d. Pyrochlore is the only detected radioactive mineral. The phoscorite sample contained $943 \mathrm{ppm}$ of $U$ and $397 \mathrm{ppm}$ of Th. (INAA method).

\section{The sample series from weathered} carbonatite

The regolith samples have been analyzed for $\mathrm{Al}, \mathrm{Ba}, \mathrm{C}, \mathrm{Ca}, \mathrm{Ce}, \mathrm{Fe}, \mathrm{K}, \mathrm{La}, \mathrm{Mg}, \mathrm{Mn}, \mathrm{Na}$, $\mathrm{Nb}, \mathrm{P}, \mathrm{S}, \mathrm{Si}, \mathrm{Sr}, \mathrm{Ta}, \mathrm{Th}, \mathrm{Ti}, \mathrm{U}, \mathrm{V}$ and $\mathrm{Zr}$ and the loss on ignition (L.I.) measured (see Fig. 6 and Tables 5 and 6 ). The statistical study is based on $12^{1}$ samples.

A strong positive correlation can be seen between the elements $\mathrm{Nb}, \mathrm{Th}, \mathrm{U}, \mathrm{Na}$ and $\mathrm{Ta}$ (Table 5), which are also the main components of the pyrochlore. The results of an R-mode rotated factor analysis are presented in Table 6. The loadings for the main components in pyrochlore are high in factor 2, which hence may be designated the pyrochlore factor.

1 The contents of $\mathrm{U}$, Th and Ta are missing for one sample

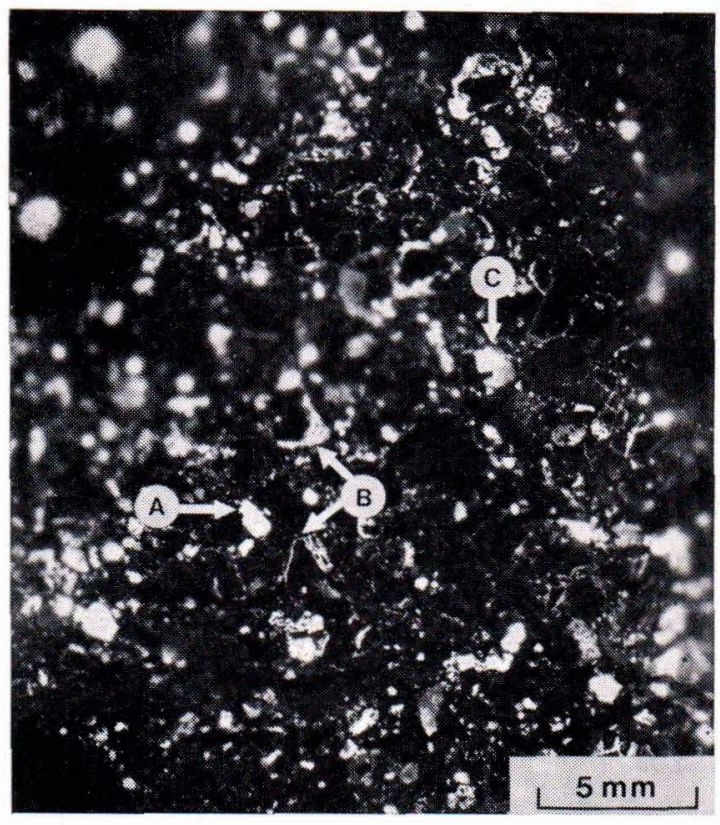

Fig. 5. Distribution of uranium in weathered carbonatite. Regolith sample M 02. Macrofol 20 $\mu \mathrm{m}$ detector, radiation time for thermal neutrons $3 \mathrm{~h}$. Uranium-bearing minerals are A) pyrochlore, B) secondary apatite and C) fine-grained limonite. The sample contained $530 \mathrm{ppm}$ of $\mathrm{U}$ and $463 \mathrm{ppm}$ of Th (INAA method).

Calcium and strontium show positive correlation to $\mathrm{P}$ and $\mathrm{C}$, which may be explained by the presence of apatite (francolite-collophane) and $\mathrm{Ca}-(\mathrm{Sr})$-carbonate. Magnetite and its weathered derivatives (iron oxides and hydroxides) may be responsible for the positive correlation between $\mathrm{Fe}, \mathrm{Mn}$ and $\mathrm{V}$. Factor 1 is considered a combined magnetite and apatite-carbonate factor. Judging from the factor loadings and correlations, uranium seems to be mainly bound in pyrochlore, or to be in close association with it, also in weathered carbonatite.

\section{Conclusions}

Pyrochlore from the Sokli carbonatite complex, northern Finland, has been studied in four phoscorite samples and in two 

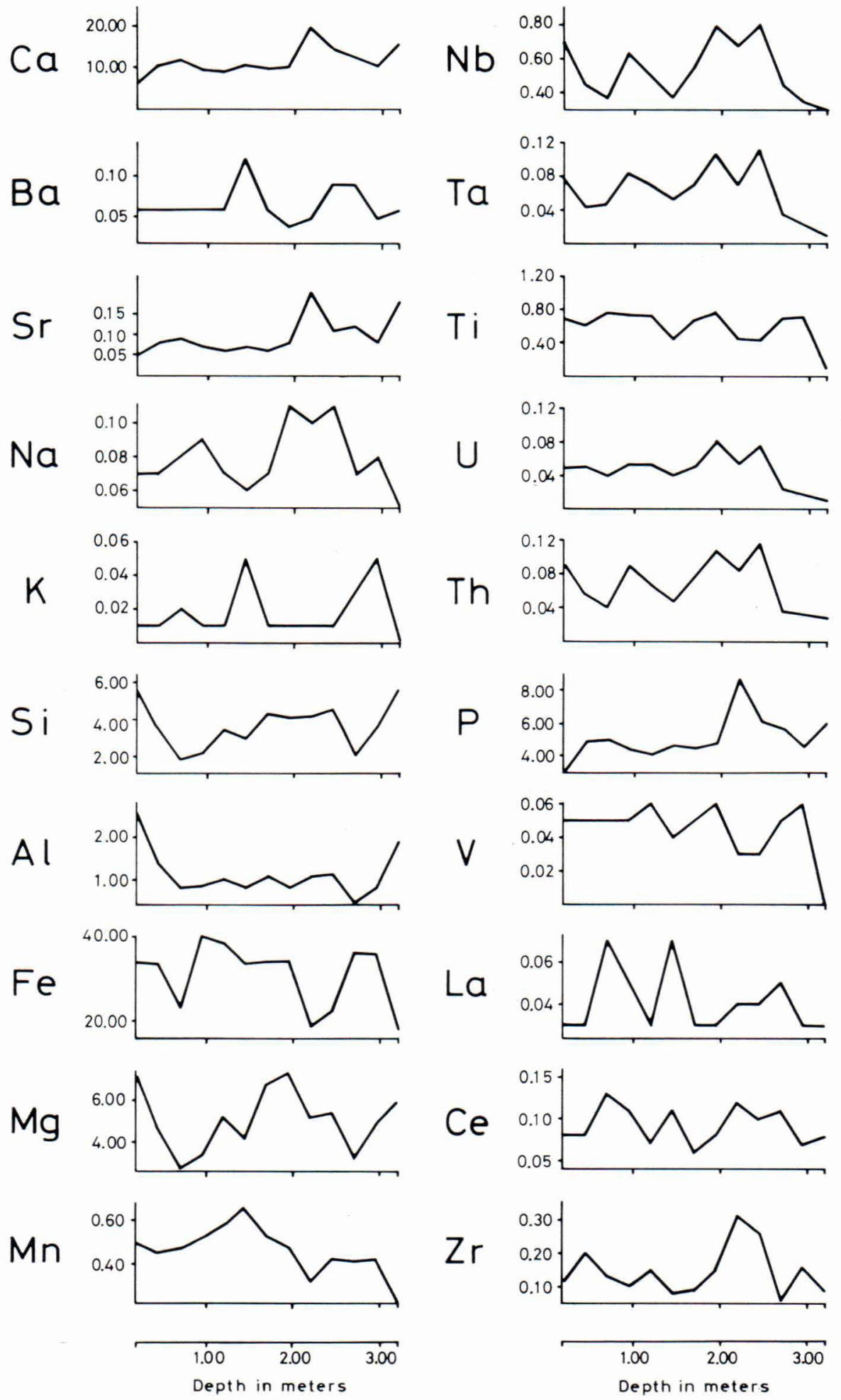

Fig. 6. Variation in the content of elements in a vertical sample series from weathered carbonatite, 


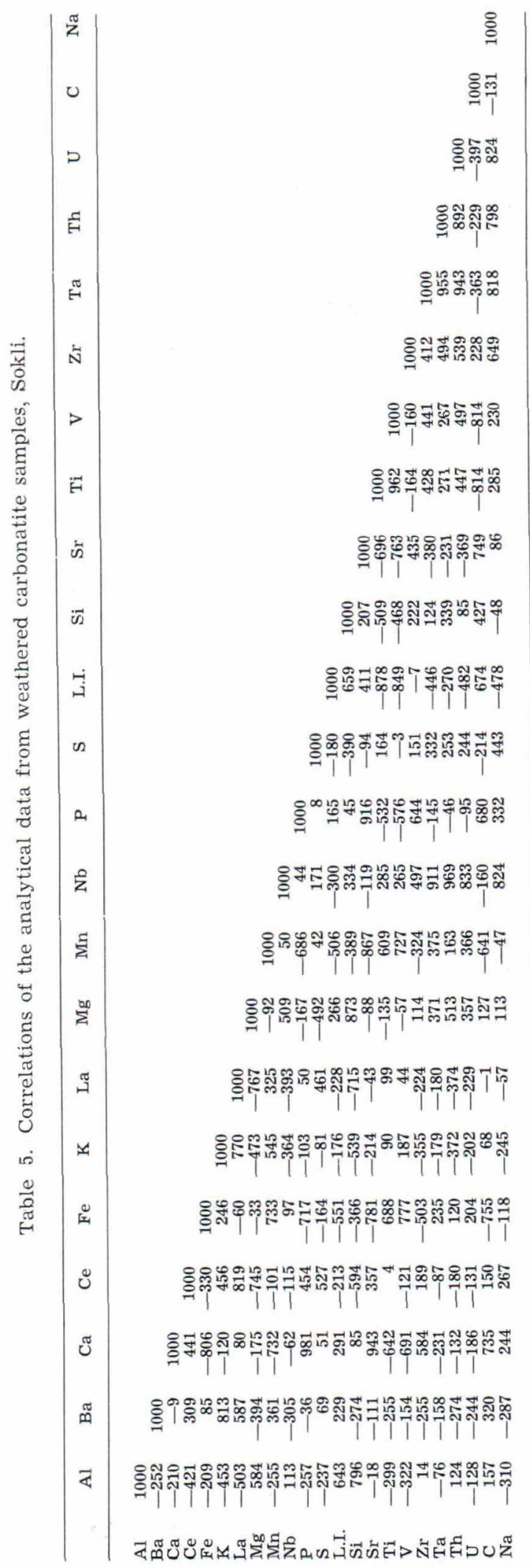

regolith samples. The pyrochlore is euhedral exhibiting crystal forms of an octahedron and a combination of an octahedron and a cube. Twinning according to the spinel law was found on two occasions and zonality is common.

The X-ray diffraction studies show that the pyrochlore is metamict. When heated up to $1000^{\circ} \mathrm{C}$, a lueshite and/or a fersmite phase crystallized in addition to the pyrochlore phase. The crystallization of lueshite seems to be favoured by the air atmosphere. The calculated cell dimensions for pyrochlore range between $10.375 \AA$ and $10.426 \AA$, with the recrystallization in an inert atmosphere resulting in larger unit cell volumes than in air. DTA/TG studies show a weak exothermal peak, possibly indicating recrystallization, at about $540^{\circ} \mathrm{C}$. The loss of weight in the experiments averages $8.9 \%$.

Electron probe microanalysis of the pyrochlore minerals proved one of them to be uranpyrochlore. The pyrochlore minerals were found to contain a notable amount of tantalum. The Ce/La-ratio varies between 3.1 and 9.6 and the $\mathrm{Nb}_{2} \mathrm{O}_{5} / \mathrm{Ta}_{2} \mathrm{O}_{5}$-ratio between 4.9 and 177.9. The low $\mathrm{Nb}_{2} \mathrm{O}_{5} / \mathrm{Ta}_{2} \mathrm{O}_{5-}$ ratio indicates that pyrochlore was crystallized in a relatively undifferentiated magma.

In weathered samples uranium is partly leached from pyrochlore and affixed to supergene minerals. The distribution studies show that uranium is enriched in secondary calcium phosphate and iron oxides. The R-mode rotated factor analysis of the sample series from weathered carbonatite revealed a pyrochlore factor and an apatite-carbonate factor. The heavy loading for uranium in the pyrochlore factor together with the correlations indicate that most of the uranium present in the weathered samples is still closely associated with pyrochlore. 
Table 6. R-mode rotated factor analysis of the correlations.

\begin{tabular}{|c|c|c|c|c|c|c|}
\hline \multirow[b]{2}{*}{$\mathrm{N}=12$} & \multicolumn{5}{|c|}{ Factor loadings } & \multirow[b]{2}{*}{$\begin{array}{c}\text { Communa } \\
\text { lity }\end{array}$} \\
\hline & 1. & 2. & 3. & 4. & 5. & \\
\hline $\mathrm{Al}$ & 0.09 & -0.04 & -0.83 & 0.29 & 0.17 & 0.82 \\
\hline $\mathrm{Ba}$ & 0.01 & -0.17 & -0.08 & -0.93 & -0.14 & 0.93 \\
\hline $\mathrm{Ca}$ & -0.99 & 0.01 & 0.10 & 0.00 & -0.08 & 0.99 \\
\hline $\mathrm{Ce}$ & -0.38 & -0.02 & 0.37 & -0.31 & -0.70 & 0.87 \\
\hline $\mathrm{Fe}$ & 0.83 & 0.01 & 0.33 & -0.09 & 0.23 & 0.86 \\
\hline $\mathrm{K}$ & 0.14 & -0.23 & 0.32 & -0.89 & -0.08 & 0.96 \\
\hline $\mathrm{La}$ & -0.00 & -0.23 & 0.33 & -0.59 & -0.65 & 0.93 \\
\hline $\mathrm{Mg}$ & 0.07 & 0.40 & -0.51 & 0.23 & 0.67 & 0.93 \\
\hline $\mathrm{Mn}$ & 0.79 & 0.17 & 0.23 & -0.46 & 0.01 & 0.92 \\
\hline $\mathrm{Nb}$ & 0.04 & 0.94 & -0.06 & 0.16 & 0.10 & 0.92 \\
\hline $\mathrm{P}$ & -0.97 & 0.10 & 0.21 & 0.00 & -0.02 & 0.99 \\
\hline $\mathrm{S}$ & 0.04 & 0.28 & -0.01 & 0.05 & -0.92 & 0.94 \\
\hline L.I. & -0.39 & -0.32 & -0.83 & -0.10 & 0.09 & 0.97 \\
\hline $\mathrm{Si}$ & -0.21 & 0.23 & -0.78 & 0.22 & 0.48 & 0.98 \\
\hline $\mathrm{Sr}$ & -0.96 & -0.15 & -0.01 & 0.13 & 0.00 & 0.97 \\
\hline $\mathrm{Ti}$ & 0.70 & 0.25 & 0.56 & 0.19 & -0.09 & 0.92 \\
\hline $\mathrm{V}$ & 0.74 & 0.27 & 0.57 & 0.06 & 0.09 & 0.95 \\
\hline $\mathrm{Zr}$ & -0.57 & 0.62 & 0.07 & 0.18 & -0.03 & 0.74 \\
\hline $\mathrm{Ta}$ & 0.26 & 0.96 & 0.03 & -0.00 & -0.04 & 0.99 \\
\hline Th & 0.13 & 0.96 & -0.13 & 0.13 & 0.04 & 0.98 \\
\hline $\mathrm{U}$ & 0.22 & 0.93 & 0.14 & 0.06 & 0.04 & 0.95 \\
\hline $\mathrm{C}$ & -0.81 & -0.14 & -0.35 & -0.31 & 0.16 & 0.92 \\
\hline \multirow[t]{3}{*}{$\mathrm{Na}$} & -0.20 & 0.39 & 0.29 & 0.14 & -0.21 & 0.97 \\
\hline & \multicolumn{5}{|c|}{ Eigenvalues } & \\
\hline & 7.7 & 6.0 & 4.6 & 1.8 & 1.3 & \\
\hline
\end{tabular}

Acknowledgements - The positive attitude of Rautaruukki Oy and a research contract with the Ministry of Trade and Industry have made this work possible. Our thanks go especially to Prof.
Heikki Paarma and Mr. Heikki Vartiainen, Phil. lic., for their encouraging support during the various phases of the study.

\section{References}

Adams, J. W. and Sharp, W. N. (1970) A convenient non-oxidizing heating method for metamict minerals. Amer. Mineral. 55, 1440-1442.

Altschuler, Z. S., Clarke, R. S., Jr and Young, E. J. (1958) Geochemistry of uranium in apatite and phosphorite. U.S. Geol. Surv., Prof. paper 314-D.

Ammon, H. L. and Mauer, F. (1967) X-ray 67, Program system for X-ray crystallography. Computer Science Center, University of Maryland.

Deutzmann, W. (1964) Erzmikroskopische Untersuchungen an Gesteinen des Kaiserstuhls Breisgau. EUR 1827. d, f, e - Les roches alcalines et les carbonatites du Kaiserstuhl, $47-64$.
Eckermann, H. von (1974) The chemistry and optical properties of some minerals of the Alnö alkaline rocks. Arkiv Mineral. Geol. 5, Nr 8, 93-210

Fawley, A. P. and James, T. C. (1955) A pyrochlore (columbium) carbonatite, Southern Tanganyika. Econ. Geol. 50, 571-585.

Frondel, C. (1958) Systematic mineralogy of uranium and thorium. U.S. Geol. Surv., Bull. 1064.

Gorzhevskaya, S. A. and Sidorenko, G. A. (1962) Phases obtained by heating minerals with pyrochlore structure and the relation of these phases to the chemical composition of the original minerals. Geochemistry 9, 912-918.

Heinrich, E. Wm. (1966) The geology of carbonatites. Rand McNally \& Co. Chicago. 
Hogarth, D. D. (1977) Classification and nomenclature of the pyrochlore group. Amer. Mineral. $62,403-410$.

Jäger, E., Niggli, E. and Veen, A. H. van der (1959) A hydrated barium-strontium pyrochlore in a biotite rock from Panda Hill, Tanganyika. Mineral Mag. 32, 10-25.

Krivokoneva, G. K. and Sidorenko, G. A. (1971) The essence of the metamict transformation in pyrochlores. Geochemistry International 8, $113-122$.

Kulp, J. L., Volchok, H. L. and Holland, H. D. (1952) Age from metamict minerals. Amer. Mineral. 37, 709-718.

Lima de Faria, J. (1958) Heat treatment of metamict euxenites, polymignites, yttrotantalites, samarskites, pyrochlores and allanites. Mineral. Mag. 31, 937-942.

- (1964) Identification of metamict minerals by $\mathrm{X}$-ray powder photographs. Junta de investigações do Ultramar. Estudos, ensaios e documentos 112.

Lovering, T. G. (1955) Progress in radioactive iron oxides investigations. Econ. Geol. 50, 186-195.

Mäkelä, M. and Vartiainen, H. (1978) A study of sulfur isotopes in the Sokli multi-stage carbonatite (Finland). Chemical Geology 21, 257265.

Paarma, H. (1970) A new found of carbonatite in North Finland, the Sokli plug in Savukoski. Lithos 3, 129-133.

- and Talvitie, J. (1976) Deep fractures - Sokli carbonatite. Department of geophysics, University of Oulu. Contribution No. 65.

Petruk, W. and Owens, D-A. R. (1975) Electron microprobe analyses for pyrochlores from Oka, Quebec. Can. Mineral. 13, 282-285.

Rehtijärvi, P. and Liehu, E. A. (1977) Isotoopin ${ }^{235} \mathrm{U}$ fissiojäljet ja uraanin jakautuminen geologisissa näytteissä, with an English summary: Nuclear tracks of ${ }^{235} \mathrm{U}$ and the distribution of uranium in geologic samples. Geologi 29, 100103.

Rozhkova, E. V., Rasumnaya, E. G., Serebryako$v a$, M. B. and Scherbak, O. V. (1958) The role of sorption in the process of uranium concentration in sedimentary rocks. Second United
Nations International Conference on the Peaceful Uses of Atomic Energy. A/CONF. 15/P/ 2059, USSR, 420-431.

Rucklidge, J. and Gasparrini, E. L. (1969) Specifications of a computer program for processing electron microprobe analytical data. EMPADR VII. Department of Geology, University of Toronto.

Safiannikoff, A. (1967) Gisement de pyrochlore de Lueshe. Soc. Géol. Belg., Ann. 90, B 461-B 486.

Semenov, E. I., Sørensen, $H$. and Katajeva, Z. T. (1968) On the mineralogy of pyrochlore from the Ilímaussaq alkaline intrusion, south Greenland. Medd. Grønland 181, Nr 7, 9-24.

Sørum, H. (1955) Contribution to the mineralogy of the Söve deposit II. X-ray and thermal studies of the niobium minerals. Kgl. Norsk. Vid. Sels. Forh. 28, 120-127.

Vartiainen, H. and Woolley, A. R. (1974) The age of the Sokli carbonatite, Finland, and some relationships of the North Atlantic alkaline igneous province. Bull. Geol. Soc. Finland 46, $81-91$.

- (1976) The petrography, mineralogy and chemistry of the fenites of the Sokli carbonatite intrusion, Finland. Geol. Surv. Finland, Bull. 280.

Veen, A. H. van der (1963) A study of pyrochlore. Ned. Geol. Mijnbouwk. Genoot., Verh., Geol. Ser. 22.

Vlasov, K. A. (editor) (1966) Mineralogy of rare elements, II. Geochemistry and mineralogy of rare elements and genetic types of their deposits. Israel program for scientific translations. Jerusalem.

Wambeke, L. van (1964) Géochimie minérale des carbonatites du Kaiserstuhl. EUR 1827. d, f, e - Les roches alcalines et les carbonatites du Kaiserstuhl 65-91.

Weijden, C. H. van der, Arthur, R. C. and Langmuir, D. (1976) Sorption of uranyl by hematite: Theoretical and geochemical implications. Geol. Soc. America, Annual meeting. Abstract with programs 8, 6 .

Wimmenauer, W. (1964) Geologisch-petrografischer Überblick. EUR 1827. d, f, e - Les roches alcalines et les carbonatites du Kaiserstuhl 17 -30 .

Manuscript received, May 10, 1979. 